\title{
Autophagy in the Immunosuppressive Perivascular Microenvironment of Glioblastoma
}

\author{
Maria L. Molina ${ }^{1,2,+}\left(\mathbb{D}\right.$, David García-Bernal ${ }^{3,+}(\mathbb{D})$, Salvador Martinez ${ }^{2}$ iD and Rut Valdor $1,3, * \mathbb{D}$ \\ 1 Brain Regionalization and Development Gene Unit at Biomedical Research Institute of \\ Murcia (IMIB-Arrixaca), 30120 Murcia, Spain; mluisa.molina@goumh.umh.es \\ 2 Instituto de Neurociencias UMH-CSIC, CIBERSAM of ISCIII, 03550 San Juan de Alicante, Spain; \\ smartinez@umh.es \\ 3 Internal Medicine Department at University of Murcia-Biomedical Research Institute of \\ Murcia (IMIB-Arrixaca), 30120 Murcia, Spain; david.garcia23@um.es \\ * Correspondence: rut.valdor@um.es \\ $\dagger$ These authors contributed equally to this work.
}

Received: 26 November 2019; Accepted: 27 December 2019; Published: 31 December 2019

check for updates

\begin{abstract}
Glioblastoma (GB) has been shown to up-regulate autophagy with anti- or pro-oncogenic effects. Recently, our group has shown how GB cells aberrantly up-regulate chaperone-mediated autophagy (CMA) in pericytes of peritumoral areas to modulate their immune function through cell-cell interaction and in the tumor's own benefit. Thus, to understand GB progression, the effect that GB cells could have on autophagy of immune cells that surround the tumor needs to be deeply explored. In this review, we summarize all the latest evidence of several molecular and cellular immunosuppressive mechanisms in the perivascular tumor microenvironment. This immunosuppression has been reported to facilitate GB progression and may be differently modulated by several types of autophagy as a critical point to be considered for therapeutic interventions.
\end{abstract}

Keywords: autophagy; chaperone-mediated autophagy; tumor; glioblastoma; perivascular cells; pericytes; immunosuppressive; tumor immune tolerance; autophagy inhibitors

\section{Introduction}

Autophagy is essential to maintain cell homeostasis, acting as a protein/organelle quality control mechanism in response to cellular or environmental stresses such as starvation, hypoxia, and chemo/radiotherapy, which is required for cancer-cell survival and the adaptation to the disturbed tumor microenvironment. Autophagy in cancer plays a dual role as a pro-tumorigenic or tumor-suppressive mechanism, which depends on the stimulus and the cell type. The effects of autophagy change in relation to the stage of tumor development and exhibit intratumoral heterogeneity, interfering with the clinical application of autophagy activators or inhibitors. During the initiation of tumor development, autophagy eliminates damaged organelles and aggregated proteins, and prevents DNA damage, protecting cells from transformation into malignant cells and promoting tumor suppression via cellular senescence [1-3]. However, once tumorigenesis is initiated, autophagy enhances establishment and progression of the tumor $[1,4-7]$.

Glioblastoma (GB), the most aggressive brain cancer, evades the immune system [8-11]. GB cells interact with cells from perivascular areas and invade the brain parenchyma forming a functional network of microtubes [12-15]. Several mechanisms have been described to favor GB progression. That is the case of stablished interactions between GB cells and tumor surrounding cells, which are essential to communicate and deliver organelles and nutrients, securing tumor survival $[13,14,16]$. Importantly, the brain immune defense fails during GB progression, preventing anti-tumor immune responses that 
may be regulated by autophagy. Autophagy keeps the homeostasis of immune cells and modulates the response to stressful stimuli. Autophagy regulates specific immune functions such as antigen presentation, cell activation and differentiation [17-20]. Thus, as it occurs with anti-cancer direct therapies, the use of autophagy modulators may affect the effectiveness of the current immunotherapies, and could strengthen the immune system to eliminate the cancer cells [21-23].

In this review, we will focus on the current findings that identify different forms of autophagy in GB cells and their functions in the tumor progression, with particular attention to perivascular brain areas, where the tumor is established and progresses, escaping from the immune system. We will describe how is the regulation and function of those autophagic pathways in immune cells, which should contribute to the brain defense against GB, but instead, support tumor growth and fail to promote anti-tumor immune responses.

Macroautophagy (also referred to as autophagy), microautophagy and chaperone-mediated autophagy (CMA) are the main known types of autophagy. Those forms of autophagy differ in how are regulated, the nature of the degraded substrates and in how the cargo is targeted to lysosomes. However, there is little data on the functions of endosomal microautophagy in tumor cells [24,25] or in the immune cells that could participate in the response to GB, macroautophagy and CMA are profusely reported to have important roles in those cell types. In this manuscript, we will review these two types of autophagy, focusing especially on CMA as an autophagy pathway that selectively degrades specific proteins that modulate tumor progression in the immunosuppressive perivascular microenvironment, which may constitute a promising target mechanism to treat this aggressive cancer.

\section{Immune Suppressive Mechanisms in the Tumor Microenvironment}

The immune system is highly specialized in the recognition of foreign antigens and unhealthy cells, including tumor cells. However, cancers have developed different strategies to escape immune system recognition and suppress the anti-tumor immune response. Specifically, it is well known that the brain tumor microenvironment is characterized by secretion of a variety of anti-inflammatory molecules, not only by tumor cells themselves, but also by other surrounding peritumoral cells previously conditioned by the tumor. These peritumoral cells are peripheral immune cells (i.e., tumor-associated macrophages (TAMs), T cells, myeloid-derived suppressor cells (MDSC) and T regulatory cells (Tregs)), and various specialized organ-resident cells including microglial cells, astrocytes and perivascular pericytes (PC) $[8,10,13]$. Collectively, anti-tumor innate and adaptive immune responses in the tumor microenvironment are altered, and several mechanisms including decreased $\mathrm{T}$ cell activation and proliferation, induction of anergic $\mathrm{T}$ cells, differentiation of Tregs, down-regulation of major histocompatibility complex (MHC) expression and polarization of macrophages to an immunosuppressive M2 phenotype, are prompted by tumor cells [22,26].

The great majority of immune cells infiltrating GB tumor mass are tissue-resident microglial cells and bone marrow-derived macrophages (BMDMs) from circulating monocytes that migrate from blood to brain parenchyma and differentiate to macrophages [22,27]. Together these cells have been called TAM/Ms". In GB, TAM/Ms displayed a pro-tumorigenic function, producing low amounts of pro-inflammatory cytokines/growth factors and down-regulating expression of co-stimulatory molecules such as CD40, CD80 and CD86 [27]. Moreover, glioblastoma and microglia interactions favor GB progression by secretion of growth factors such as epidermal growth factor (EGF) and colony stimulating factor-1 (CSF-1), or by up-regulation of CD163 and CD204 in infiltrating TAM/Ms, mechanism that has been associated with a worse prognosis. TAM/Ms have been also described to be involved in brain tumor angiogenesis and resistance to anti-angiogenic therapies [28], and to stimulate glioma stem cell invasion through transforming growth factor $\beta$ (TGF $\beta$ ) signaling [29]. Other anti-inflammatory cytokine, IL-10, which is related to impaired T cell responsiveness in gliomas, is selectively up-regulated in those tumors with invasive behavior compared to less malignant counterparts [30]. 
GB cells are also able to avoid anti-tumor $\mathrm{T}$ cell responses by several mechanisms, such as prevention of antigen processing and presentation on MHC-class I, up-regulation of PD-L1 expression, the ligand of the negative regulator receptor of T cell activation PD-1 (programmed cell death protein 1), or by increasing infiltration of Tregs and T cells with high expression of PD-1 and CTLA-4 (cytotoxic T-lymphocyte-associated protein 4) [22,31,32].

PC have recently gained special attention due to their role in GB progression. PC are located on the abluminal vessel wall, regulating vascular tone and morphology, and represent an immunological defense in the brain modulating neuroinflammation [33-35]. However, PC also express PD-L1 and acquire an immunosuppressive phenotype upon GB interaction, assisting GB to escape the immune system recognition $[13,36]$.

Many studies have provided compelling evidence that autophagy is involved in central nervous system (CNS) tumor recurrence, and in chemotherapy and radiotherapy resistance [37], suggesting that autophagy is other highly regulated mechanism that may contribute to tumor-induced immune tolerance.

\section{Autophagy in GB}

\subsection{Macroautophagy}

Macroautophagy, also known as autophagy, is a process of lysosomal degradation and recycling of cellular components by sequestering of cytosolic regions in de novo-generated double membrane vesicles known as autophagosomes. Formed autophagosomes end up fusing with lysosomes to degrade their contents. Macroautophagy can be either in bulk or selective. The selectivity is mediated by autophagy receptors that bring cargo to the phagophore, including damaged organelles, intracellular bacterial pathogens and aggregated proteins (Figure 1) [1,2,24,38-41].

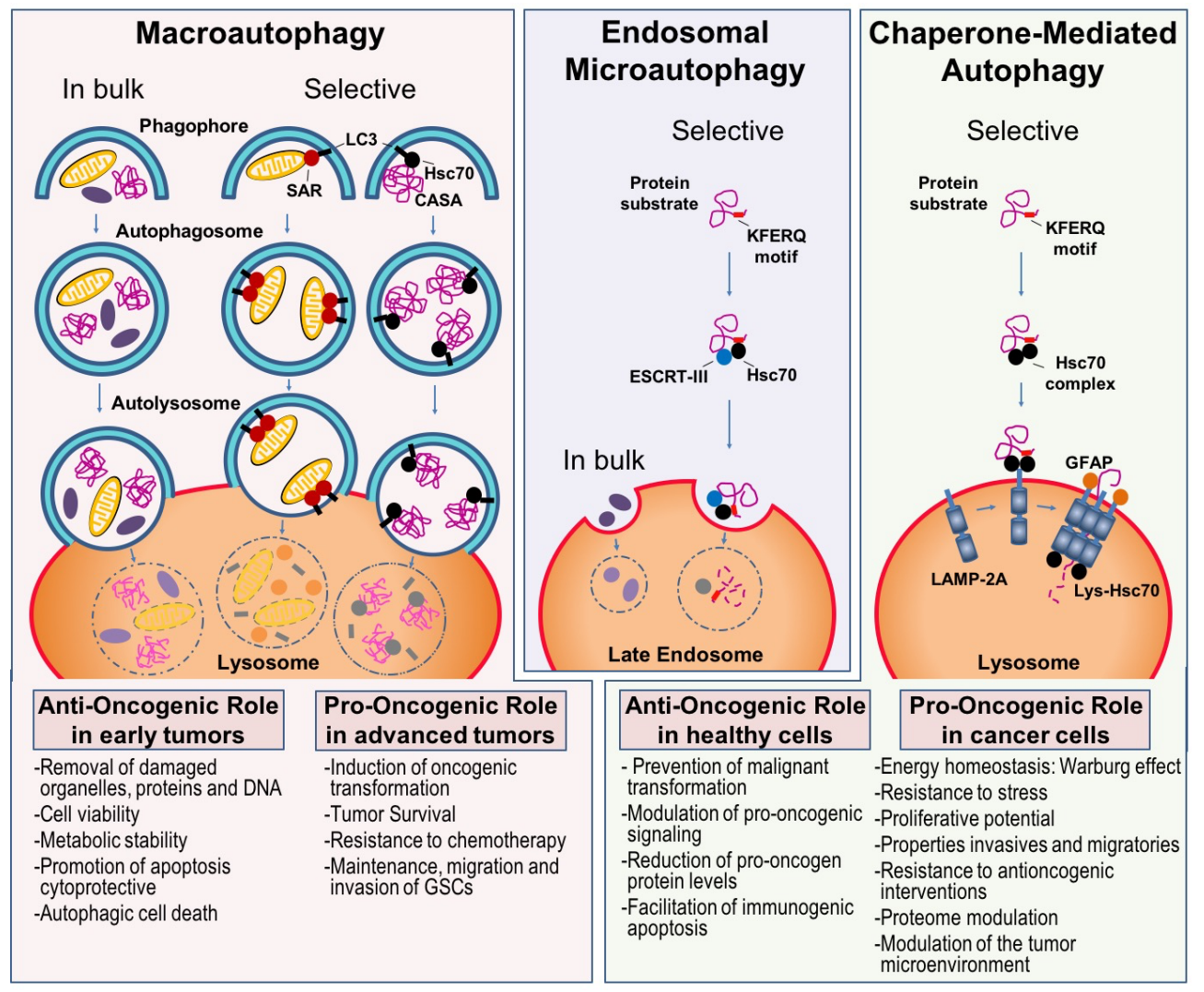

Figure 1. Types of autophagy in mammals and their anti- and pro-oncogenic roles. Macroautophagy, is a process of lysosomal degradation and recycling of cellular components, including damaged organelles, 
intracellular bacterial pathogens, and aggregated proteins. Macroautophagy sequesters cytosolic contents in de novo-generated double membrane vesicles called autophagosomes that finally fuse with lysosomes. Macroautophagy can be either in bulk or selective for a kind of cargo, and selectivity is mediated by selective autophagy receptors (SAR), or Hsc70 chaperone for protein aggregates in the case of Chaperone-Assisted Selective Autophagy (CASA). Selective macroautophagy binds cargo to the phagophore through lipidated LC3 proteins anchored to the latter's membrane. Endosomal microautophagy, termed microautophagy in mammalian cells, caters on the degradation of cytosolic regions by late endosomes recognizing the substrates to be degraded, both by bulk degradation of proteins present in cytosol trapped in vesicles forming at the late endosome membrane, and by a selective degradation after binding to Hsc70 chaperone though KFERQ-like motifs. Latter are sorted into intraluminal vesicles in a manner dependent on the endosomal sorting complex required for transport III (ESCRT-III). CMA is a selective process of degradation of soluble, amenable to unfolding, cytosolic proteins presenting KFERQ-like motifs. The chaperone Hsc70 recognizes the motifs and transports the protein substrates to the lysosome where they bind to LAMP2A. LAMP2A multimerizes being stabilized by a glial fibrillary acidic protein (GFAP) and upon unfolding, the substrate is translocated through the lysosomal membrane with the assistance of a lysosomal resident Hsc70, and degraded in the lysosomal lumen. Both macroautophagy and CMA have anti- and pro-oncogenic roles, which depend on the cellular context and are summarized here.

\subsubsection{Regulation}

Under normal conditions, basal level of autophagy is very low. Therefore, autophagy must be induced through an efficient mechanism to survive stress and adapt extracellular signals. In mammalian cells under nutrient-rich conditions, autophagy is inhibited by the serine/threonine-protein kinase mTOR (mammalian target of rapamycin). mTOR negatively regulates other serine/threonine kinases, Unc-51-like kinase-1 (ULK1) and -2 (ULK2), phosphorylating and inactivating Unc-51-like kinases (ULKs) and autophagy-related gene 13 (Atg13) by binding to the ULKs-Atg13-FIP200 complex [42].

Under conditions of nutrient stress, AMP-dependent protein kinase (AMPK) increases autophagy by inhibition of mTOR complex 1 (mTORC1), via phosphorylation of its Raptor subunit. Then, ULK1 and ULK2 are activated and phosphorylate Atg13 and FIP200. The beclin1 complex is recruited and activates the class III PI3K VPS34, stimulating the autophagosome nucleation [42,43]. In addition, other studies demonstrate that inhibition of mTORC1 promotes the transcription factors EB (TFEB) and E3 (TFE3) nuclear translocation, inducing expression of autophagy-lysosome-relevant genes [44,45]. Autophagy is also induced by Exchange protein directly activated by cAMP 1 (Epac-1) through a $\mathrm{Ca}^{2+/}$ calmodulin-dependent kinase kinase $\mathrm{b}(\mathrm{CaMKKb}) / \mathrm{AMPK}$ signaling pathway [46]. Recently, inositol polyphosphate multikinase (IPMK) has been reported to induce autophagy through the regulation of AMPK/ULK activation and by enhancing autophagy-related transcription dependent of Sirt-1 activation [47].

In tumor cells, there are many signaling pathways that participate in the regulation of autophagy. Down-regulation of STAT/BCL2/BECLIN-1 [48-50] and PI3K/Akt/mTOR-mediated signaling pathways can activate macroautophagy [51-53]. The Ras/Raf/ERK signaling pathway is one of the most frequent pathways that activate macroautophagy in tumors [54,55]. Other important modulators of macroauthophagy in GB are Sirt1 that induces autophagic cell death and mitophagy [56], insulin, p53 [57], p38 mitogen-activated protein kinase (p38-MAPK) [58], 5' AMPK [59], phosphatase and tensin homolog deleted from chromosome 10 (PTEN) [60], and reactive oxygen species (ROS)-associated pathways [61]. Furthermore, intracellular calcium signaling seems also an important regulatory pathway in GB $[62,63]$. Recent advances in Hedgehog, NRF2-P62, and PD-L1/PD1 signaling pathways seem to indicate that these might be potential targets to modulate macroautophagy in glioma [64-66].

It is important to highlight that in cancer cells, in general, acute amino acid starvation induces two responses in parallel: mTOR inactivation with subsequent activation of in-bulk macroautophagy, and induction of an immediate selective endosomal microautophagy independent of mTORC1 inactivation 
and canonical macroautophagy [24] (Figure 1). Both autophagic pathways likely work in concert and may partially compensate for each other [67].

\subsubsection{Functions}

Most cells sustain low basal levels of macroautophagy that serve as a quality control system to selectively degrade labeled damaged cargo [41,68-72]. However, autophagy plays a dual role in GB as in other types of cancer, mediating oncogenic or oncosuppressive effects, acting as a "double-edged sword" in tumors, depending on the cellular context and tumor type, the stage of tumor, cell viability and intracellular environment $[1-3,6]$.

In the early stages of oncogenic transformation, damaged proteins and organelles are efficiently removed by macroautophagy, maintaining cell homeostasis, metabolism, and viability, which prevents further tumor development [2,3]. Macroautophagy also prevents the accumulation of toxic molecules, such as ROS produced by dysfunctional mitochondria, in addition to aggregates of ubiquitinated proteins [73]. In addition to cytoprotective effects, autophagy exerts a death stimulation function known as autophagy-dependent cell death, which is due to an excessive degradation of cell components and organelles [3,74]. Moreover, several studies indicate that macroautophagy is activated in response to several stressors, promoting glioma apoptosis $[73,75,76]$.

Regarding the role of macroautophagy in epithelial-mesenchymal transition (EMT) of GB stem cells, several studies implicate it in the promotion of EMT, while other works controversially suggest that its inhibition may promote EMT and induce cancer-cell invasion [73,77,78].

During the advanced stages of tumors, macroautophagy is up-regulated, playing a crucial role in the survival and development of GB, providing metabolic support and preventing senescence [6,7,79-81], conferring resistance to chemotherapy, as well as supporting the maintenance, migration and invasion of GSCs $[73,82,83]$.

Therefore, treatment of tumors via macroautophagy regulation is extremely complicated because it can be involved in cancer-cell survival or death. In addition, controversial results on macroautophagy quantification in GB still exist in the literature. In fact, misinterpretations often occur when assessing macroautophagy activity, which is often quantified by an increase in LC3 levels, which does not necessarily reflect increased macroautophagy, since it may be due to an accumulation of autophagosomes that do not fuse with lysosomes. Thus, the assessment of macroautophagy status depends on a careful evaluation of several macroautophagy markers, such as LC3-I/II ratio, subcellular localization, Atg12-Atg15 accumulation, and p62 degradation along with an assessment of the macroautophagy flux [84].

\subsection{Chaperone-Mediated Autophagy}

CMA is a selective process of lysosomal degradation of soluble cytosolic proteins with KFERQ-like motifs. The chaperone heat shock cognate $71 \mathrm{kDa}$ protein (Hsc70) binds to the substrate protein by recognition of the specific motifs and carry it to the lysosome with the help of another cochaperones. The protein binds to the CMA receptor at the lysosomal membrane, the limiting component of this pathway known as lysosome-associated membrane protein type 2A (LAMP2A). The protein is unfolded and translocated into the lysosome to be degraded, also contributing other resident Hsc70 in the lysosomal lumen (Figure 1) [85].

\subsubsection{Regulation}

Basal CMA levels are detectable in almost all types of mammalian cells, and its regulation is critical to maintain cellular function and homeostasis. CMA failure leads, instead, to intracellular accumulation of damaged proteins, defective regulation of many cellular functions, and failed responses to different stressors [86-89]. CMA in tumor cells seems to be constitutively up-regulated [5]. Starvation, hypoxia, and ROS, characteristics of the tumor microenvironment, activate CMA, but the mechanisms of increased CMA activity in cancer cells are still poorly understood [87,89-94]. 
Although there are no studies on how CMA is regulated in GB cells, it is interesting to consider that mechanisms of CMA up-regulation in some cancer cells are the same as in non-transformed cells $[95,96]$. In fact, during starvation, normal cells increase the levels of lysosomal LAMP2A by reducing its lysosomal turnover [97], and in a same way, colorectal cancer cells up-regulate LAMP2A by reducing their degradation through lowering levels of sorting nexin 10 (SNX10) [95]. Conversely, other cancer cells use similar mechanisms as healthy cells, but with different results [98]. That is the case of Hsp90 inhibition, which causes reduction of CMA activity by decreasing LAMP2A stabilization at the lysosomal membrane in non-transformed cells, whereas in pancreatic cancer cells, Hsp90 inhibition induces CMA activity and promotes IGF-1R $\beta$ degradation [98]. In other cancer cells, pathways that down-regulate CMA in normal cells, appear not to be functional. That is the case of several cancer-cell lines that up-regulate CMA even in the presence of TORC2/AKT1 signaling pathway, which has a CMA inhibitory effect in normal cells [99].

In most cell types, CMA blockade in vitro and in vivo causes the activation of macroautophagy and the proteasome system $[88,100]$. Vice versa, the inhibition of macroautophagy or proteasome activates CMA [101-104], which could be important for the maintenance of cell quality control and energy balance at baseline conditions. However, although some cancer cells retain this autophagic crosstalk, in most cancer cells, CMA is constitutively activated independently of the status of macroautophagy [5].

\subsubsection{Functions}

CMA is implicated in a wide variety of cellular functions such as protein quality control, response to starvation, anti-ageing functions, transcriptional regulation, immune response, cell cycle and cancer biology (Figure 1). CMA blockage in cancer cells has anti-cancer activity, decreasing cell proliferation and tumorigenic/metastatic ability [4,5]. However, both reduced and increased CMA activity can be pro-oncogenic depending on the cellular context, as reduced CMA increases DNA damage and decreases proteostasis [94], providing an environment that facilitates malignant transformation [105]. However, once cells have undergone transformation, they up-regulate CMA to protect against oxidative damage [4], degrade negative regulators of cell proliferation [106] and anti-oncogenes [107] and maintain the metabolic switch favorable for cancer-cell growth [108,109]. Abnormally high levels of CMA are shown in many cancer-cell lines and different types and stages of human tumors [4,5,110]. In fact, genetic blockage of CMA in cancer-cell lines reduced their tumorigenic ability and CMA inhibition in preformed xenografted tumors induced tumor shrinkage and lowered metastasis number [5].

Many cancer cells need CMA up-regulation to sustain aerobic glycolysis (Warburg effect), required for cancer progression [5,109]. CMA plays an important role under hypoxia conditions in the regulation of the tumor metabolism by degrading cell cycle regulatory proteins such as phosphorylated serine/threonine-protein kinase (CHK1) [111] and hypoxia-inducible factor $1 \alpha$ (HIF1 $\alpha)$ [112,113]. In addition, quantitative proteomics analysis of isolated lysosomes from CMA-activated conditions in cancer cells has recently revealed a new role for CMA in the control of cell translation [114]. Importantly, up-regulated CMA may also assist chemoresistance of GB, making them more resistant to different stressors such as oxidative stress, hypoxia or even DNA damage agents [4,115]. Up-regulation of CMA in GB cells that are in contact with perivascular areas, not only favors their proliferation, but it may even interfere with the aberrant CMA up-regulation in tumor surrounding cells that benefits tumor survival and affects anti-tumor immune microenvironment responses [36].

\section{Autophagy in Immunosuppressive Cells during GB Progression}

Immune cells can be modulated during tumor progression by autophagy activation or inhibition, allowing them to promote anti-tumor immune responses or to fail in tumor clearance by inducing tumor immune tolerance. Next, we describe autophagy in the different types of cells best known to contribute in the immunosuppressive microenvironment of GB. 


\subsection{Macroautophagy in Innate Immune Response}

Macrophages and microglia are the main innate immune cells of the CNS which usually facilitate tumor-mediated immunosuppression and tumor progression [22,27]. Infiltrated macrophage populations contribute to up to $50 \%$ of non-neoplastic cells in the tumor microenvironment [27] and require autophagy to maintain immune homeostasis. Macrophages use LC3-associated phagocytosis (LAP), a type of non-canonical autophagy, to eliminate cells captured in phagosomes that fuse to the lysosome, during tissue maintenance [18]. The failure of this pathway promotes impaired degradation of phagocytosed cells, inducing systemic inflammatory disease that can help anti-tumor immunity [17] (Figure 2). Induction of autophagy by activating c-Jun N-terminal kinase (JNK) and blocking ATG5 cleavage is essential for differentiation of monocytes into macrophages, preventing monocyte apoptosis and inducing cytokine production in response to granulocyte-macrophage colony-stimulating factor (GM-CSF) [116]. Autophagy also plays an important role in MDSC polarization. The inhibition of autophagy in macrophages (i.e., by knocking out Atg5 gene expression) promotes M1 polarization $[117,118]$. Furthermore, activation of autophagy in response to colony-stimulating factor-1 (CSF-1) and through AMPK signaling causes monocytes to differentiate into immunosuppressive M2-like macrophages, contributing to tumor progression [17]. Blocking autophagy due to decreased ATG16L1 expression enhances production of the pro-inflammatory cytokines IL-1 $\beta$ and IL-18, suggesting that autophagy regulates inflammasome activation and controls production of those cytokines [119] (Figure 2).

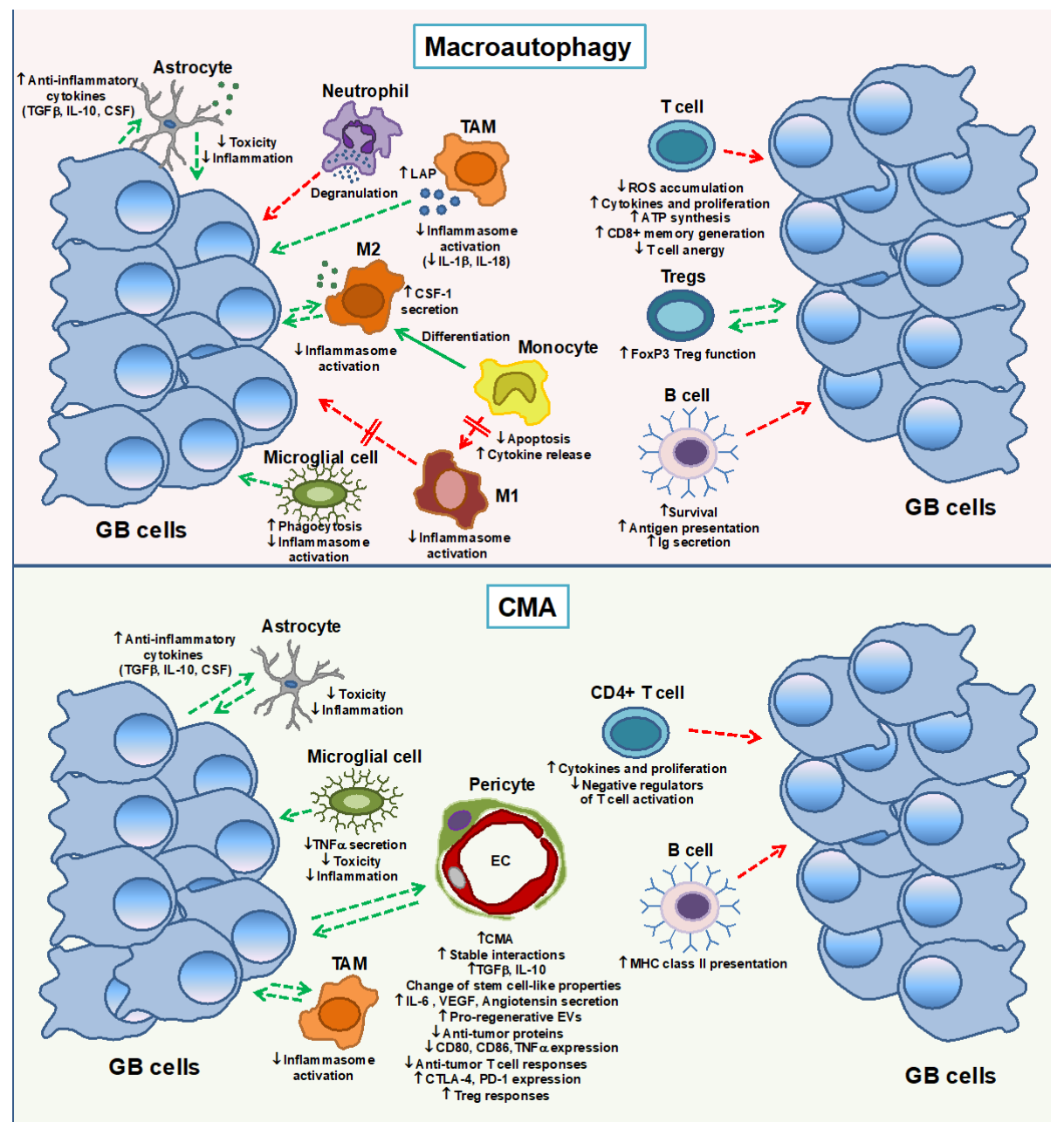

Figure 2. Autophagy function in the immune responses of peritumoral cells during GB progression. 
Macroautophagy and CMA activation in different immune or brain-resident cells, represents a key point of regulation to favors progression of tumor cells (green arrows) or to promotes its anti-tumor activity (red arrows), respectively. Macroautophagy and CMA up-regulation support tumor progression by increasing phagocytosis and by inhibiting inflammasome-mediated responses of TAMs and microglial cells, and by stimulating differentiation of monocytes into anti-inflammatory M2 macrophages. However, macroautophagy promotion hinders polarization of monocyte into pro-inflammatory M1 macrophages, which may represent an indirect mechanism to advantage tumor progression. Astrocytes have direct physical contact with tumor cells whereas macroautophagy/CMA activity in this cell type contributes to its anti-inflammatory phenotype. Neutrophils require macroautophagy to exert its anti-tumor activity. Regarding the adaptive immune responses, $\mathrm{T}$ cells has been shown to require macroautophagy and CMA to develop its anti-tumor activity by regulation of several immune checkpoints (i.e., increasing cytokine release, proliferation, energy store mobilization, and degradation of negative regulators of $\mathrm{T}$ cell activation or by prevention of $\mathrm{T}$ cell anergy). Macroautophagy and CMA are also necessary for maintaining B cell-specific functions such as antigen presentation. However, macroautophagy promotion favors tumor tolerance by stimulation of FoxP3 T regulatory cell function. GB-induced CMA modulates pericytes immune function through cell-cell stable interactions promoting GB survival and progression. GB-conditioned pericytes display an aberrant up-regulation of CMA that lead to secretion of anti-inflammatory cytokines, angiogenic molecules, pro-regenerative extracellular vesicles, and prevention of anti-tumor proteins secretion that benefits tumor growth. Furthermore, GB-induced CMA in PC down-regulates expression of co-stimulatory molecules, prevents pro-inflammatory cytokine secretion and fails to promote anti-tumor T cell responses, enhancing Treg responses, which contributes to the immunosuppressive peritumoral niche of GB. Ig: immunoglobulins; EVs: extracellular vesicles; EC: endothelial cells.

By contrast, neutrophils, other type of myeloid-derived cells that can develop an immunosuppressive function in GB [120], require macroautophagy to induce inflammation [121,122]. Microglia, the tissue-resident macrophage population of the brain, also require autophagy to maintain their ability to phagocytose apoptotic cells, protein aggregates and debris, and its failure enhances inflammation as it occurs in macrophages [17]. Several publications show activation of primary mouse microglia or microglial cell lines after knockdown of autophagy genes (i.e., Atg5 or Atg7) [123-125], and characterize how the inflammatory response can be modulated by Beclin1-driven autophagy through NLRP3 degradation [126] (Figure 2).

Reactive astrocytes establish direct cell interactions by gap junctions with tumor cells and microglial cells at the peritumoral glial scar favoring tumor progression and chemoresistance. Astrocytes contacting tumor cells secrete cytokines that support tumor metastasis in the brain and contribute to an immunosuppressive microenvironment with high levels of anti-inflammatory cytokines such as IL-10, TGF $\beta$ and CSF [10]. Autophagy/lysosomal dysfunction in astrocytes participates in neurodegeneration as observed in lysosomal storage disorders [127]. However, little is known on the possible role of macroautophagy in the immune function of astrocytes. Recent works show that this process is needed for the homeostasis maintenance upon stimulation, but depending on the type of stressor, it can also facilitate cell death and therefore brain inflammation [128-130] (Figure 2).

In summary, inhibition of macroautophagy in MDSC and glia lead to a pro-inflammatory response that might alert the immune system to regress the tumor progression. However, it is important to consider that macroautophagy inhibition can also impair phagocytosis and promote high toxicity and inflammation, which can contribute to neurodegeneration associated with different diseases $[125,126]$.

\subsection{Macroautophagy in the Adaptive Immune Response}

T cells, which can infiltrate the brain to promote tumor clearance, are found in peritumoral areas during GB progression, being affected by several immune checkpoints that impair effective anti-tumor responses. Macroautophagy role is essential in the maintenance of $\mathrm{T}$ cell homeostasis for the turnover of organelles such as mitochondria. Macroautophagy prevents increased ROS accumulation that lead to higher rates of cell death [131,132]. Macroautophagy inhibition deleting Atg gene or using chemical 
inhibitors negatively impacts the responses to antigen. Thus, it impairs activation-induced proliferation upon T-cell receptor (TCR) engagement, which is associated with fast increased calcium levels [133]. Furthermore, recent works have shown selective degradation of inhibitors of cyclin-dependent kinases or TCR signaling proteins, which contribute to T cell proliferation [132,134]. Importantly for tumor progression, the accumulation of the protein tyrosine phosphatase PTPN1 in autophagy-deficient CD4 ${ }^{+}$ $\mathrm{T}$ cells produces failed $\mathrm{T}$ cell responses upon priming and also after subsequent stimulation, which seem to indicate that macroautophagy also regulates T cell tolerance [134]. Interestingly, IL-2 receptor signaling enhances macroautophagy in peripheral $\mathrm{CD}^{+} \mathrm{T}$ cells by increasing LC3 expression, whereas IFN- $\gamma$, T helper 1 cells signature cytokines, promotes macroautophagy in macrophages via the p38 MAPK signature pathway [135,136] (Figure 2).

Autophagy maintains the energy demands of the metabolism of $\mathrm{CD}^{+}{ }^{+} \mathrm{T}$ cells, contributing to sustain adenosine triphosphate (ATP) production in response to TCR engagement, proper anaerobic glycolysis and mitochondrial respiration [133,134]. Autophagy-related (ATG) proteins-dependent autophagic pathways also modulates $\mathrm{T}$ cell differentiation and function, regulating the generation of different $\mathrm{T}$ cell populations [20]. Autophagy is also needed in FOXP3 ${ }^{+}$regulatory T cells (Treg) to suppress anti-tumor immune responses, maintaining Treg cell homeostasis by prevention of metabolic alterations that decrease their survival and may lead to autoimmunity [137]. Importantly, CD8 ${ }^{+} \mathrm{T}$ cell memory generation and maintenance require of autophagy activity [138]. Recent works indicate that the ability of autophagy to reprogram $\mathrm{CD}^{+} \mathrm{T}$ cell metabolism, contributes in modulation of the efficacy of anti-tumor $\mathrm{CD}^{+} \mathrm{T}$ cell responses $[139,140]$ (Figure 2).

Less has been reported about B cells in GB; however, it is important highlight that this type of cell may possibly infiltrate GB during progression or regression after therapy, since they can act as antigen-presenting cells (APCs) and may modulate tumor antigen-specific T cells [141,142]. IL-4, a signature cytokine of T helper 2 cells can induce autophagy in B cells via a PI3K-dependent pathway, promoting survival and antigen presentation of B cells [143]. Furthermore, macroautophagic activity regulates B cell development, and its failure, leads to defective humoral immune response with reduced secretion of immunoglobulins and failed activation upon the engagement of the $B$ cell receptor (BCR) [144,145] (Figure 2).

\subsection{CMA in Innate Immune Response}

Although little is known today about the role of CMA in the innate immune response, and even less in the GB microenvironment, recent studies point to an increase in CMA in astrocytes and microglia, as a protective mechanism against pathogenic crosstalk with neurons that causes toxicity, inflammation and neurodegeneration [146,147]. A recent study in TAMs shows that LAMP2A expression is up-regulated by tumor cells in several mouse tumor models and cancer patients' samples. Suppression of Lamp2a gene expression by either shRNA or CRISPR/Cas9 prevents TAMs activation and tumor growth, whereas substrates degradation by CMA seems to promote macrophage pro-tumorigenic activation [148] (Figure 2).

Recent studies of our group have revealed a new role of CMA in the immune function of perivascular cells PC during GB progression and through interaction with tumor cells [13,36]. PC initiate aberrant degradation of proteins in response to a burst of oxidative stress upon GB interaction, changing the levels of secretion of several cytokines and of growth factor release, in a manner that supports tumor cell proliferation and GB survival. GB induces CMA in PC to modulate stem-cell-like properties and prevent secretion of anti-tumor proteins, facilitating tumor growth. Furthermore, GB-induced CMA in PC enhances secretion of the anti-inflammatory cytokines TGF $\beta$ and IL-10 to promote an immunosuppressive phenotype that leads to failed tumor antigen-specific $\mathrm{T}$ cell responses, facilitating tumor tolerance. In a mouse model of xenografted GB cells, PC with impaired CMA, by knocking out Lamp2a expression, promote antigen-specific $\mathrm{T}$ cell infiltration in the peritumoral areas, resulting into tumor elimination. FOXP3 ${ }^{+}$Tregs populations hardly were infiltrated in those areas and reduced expression of immune checkpoints, such as CTLA-4 and PD-1 in T cells, was detected [36]. This work 
supports that CMA inhibition in specific cells of the innate immune response of the brain, such as PC, may be an effective approach to treat this aggressive disease (Figure 2).

\section{4. $C M A$ in the Adaptive Immune Response}

So far, the role of $\mathrm{CMA}$ in $\mathrm{CD}^{+} \mathrm{T}$ cells in anti-tumor immunity is unknown. In $\mathrm{CD}^{+} \mathrm{T}$ cells, CMA is essential for $\mathrm{T}$ cell activation, and its failure has been shown to impair $\mathrm{T}$ helper cell responses to immunization and to infection by pathogens such as Listeria monocytogenes. CMA selectively degrades two negative regulators of T-cell activation, the itchy homolog E3 ubiquitin protein ligase (ITCH) and the regulator of calcineurin 1 (RCAN1), following stimulation of the TCR. High levels of those CMA substrates are accumulated in CMA-deficient $\mathrm{T}$ cells and are responsible for decreased cytokine release and $T$ cell proliferation upon T cell activation [89] (Figure 2). Importantly, decreased or dysregulated CMA with age in T cells, which also occurs in macroautophagy, may translate into altered quality control, energy balance and proteome remodeling. Therefore, it would be also important to consider the age to modulate autophagy in future therapies of GB that may affect T cells [20].

Finally, the important role of CMA in MHC-class II presentation of cytoplasmic antigens by B cells $[149,150]$ should be also considered during GB progression [141,142], since CMA in B cells might facilitate anti-tumor $\mathrm{T}$ helper responses (Figure 2).

\section{Are Drugs Targeting Autophagy an Effective Anti- GB Tumor Therapy?}

Despite significant advances in conventional first-line therapeutic strategies for primary GB (i.e., surgical resection, radiotherapy and chemotherapy), tumor reappears in almost all patients, showing a median survival of 12-15 months from initial diagnosis. Therefore, new therapeutic approaches enhancing effectiveness of GB treatment are urgently needed.

As mentioned previously, macroautophagy and CMA are up-regulated in most tumors [5,53,94,151,152], being the first even more increased after radiation and chemotherapy [37]. Autophagy has been considered to be a promising therapeutic mechanistic target to prevent progression of a variety of tumors including GB [36,81]. Chloroquine and hydroxychloroquine are the only available macroautophagy inhibitors in the clinical practice and they have already been used in several clinical trials, alone or in combination with temozolomide (TMZ), showing a significant increased survival in patients with GB $[153,154]$. Other reported macroautophagy inhibitors that sensitize GB cells to chemotherapy are 3-methyladenine, wortmannin, bafilomycin A1 or siRNA for knocking down expression of Rab7 or Atg7 genes [155-157]. However, it must be taken in consideration that autophagy activation may also have deleterious effects on tumor cells, as a persistent stimulation of autophagy may result in cell death. That is the case of rapamycin, LY294002, arsenic trioxide or tamoxifen [157]. Combination of drugs which increase autophagic flux such as tricyclic antidepressants (TCAs) and certain anticoagulants (inhibitor of the purinergic receptor P2Y12) promotes autophagy-associated cell death in glioma cells [158].

Considering that CMA regulatory mechanisms in some cancer cells act differently than in healthy cells [94] (Figure 1), several CMA control points reported must be validated in each type of cancer: (1) the first one is constituted by three proteins: mTOR2, Akt, and PHLPP1. While mTOR2 and Akt inhibit CMA, dynamic recruitment of PHLPP1 to lysosomal membrane neutralizes this inhibitory effect and activates CMA. This signaling axis may be blocked by using a selective inhibitor of PHLPP1 [99]; (2) under conditions of oxidative stress, the transcription factor known as nuclear factor of activated T-cells (NFAT) induces Lamp2 expression, an effect that is prevented by the calcineurin inhibitor cyclosporine A or by blockade of ROS production by the anti-oxidant $\mathrm{N}$-acetyl-cysteine [89]; (3) the transcription factor nuclear factor, erythroid derived 2, such as 2 (NFE2L2/NFR2) regulates expression of Lamp2a, being the NFE2L2 deficiency associated with reduced LAMP2A levels [159]; (4) retinoic acid receptor alpha $(\operatorname{RAR} \alpha)$ has been found to negatively regulate LAMP2A expression, and the RAR $\alpha$ activator all-trans retinoic acid (ATRA) acts as a potent LAMP2A inhibitor [160]; (5) endoplasmic reticulum (ER) stress mediates p38MAPK activation which in turns phosphorylates 
LAMP2A and promotes CMA, a mechanism termed "ERICA" (ER stress-induced chaperone-mediated autophagy) [161]; (6) Phosphopeptide P140, a fragment of the spliceosomal SNRNP70/U1-70K protein, has been reported to alter the composition of HSPA8/HSC70 complexes and down-regulates LAMP2A expression, thereby reducing CMA [162]; and (7) Unlike LAMP2A, the only LAMP2 isoform that participates in CMA, LAMP2C negatively regulates melanoma growth and survival [163].

Antibiotics, such as cycloheximide, anisomycin and SB230580 seem to affect CMA activity whereas geldanamycin acts as a CMA activator in some contexts [164], but selectively inhibits chaperone Hsp90 in others, inhibiting CMA in some types of tumor cells and showing anti-cancer activity $[165,166]$. However, as some of the cell components that control macroautophagy and CMA at different levels are also involved in other signaling pathways that regulate key cellular processes other than autophagy, pharmacological activation, or inhibition of any of these proteins could have significant non-specific unwanted adverse effects.

Conversely, and although specific chemical inhibitors of CMA are not currently available in clinic, expression levels and assembly of LAMP2A to the lysosomal membrane represent the only limiting factor to regulate CMA activity [88]. In this regard, gene therapy directed to CMA only by blocking LAMP2A expression could provide a much greater specificity to this type of anti-cancer strategies. Thus, it has been found that blockade of LAMP2A expression delays growth and inhibits metastasis of a variety of solid tumors $[4,5,94,167]$. In the case of GB, it has been recently addressed for the first time that GB not only increase its CMA to survive and progress but GB cells also induce an abnormal up-regulation of basal CMA in PC of brain peritumoral areas, to modulate PC immunosuppressive phenotype through cell-to-cell interaction and facilitate GB progression [36]. Accordingly, inhibition of CMA in PC (i.e., by knocking out LAMP2A expression) destabilizes GB-PC interactions and promotes a secretory function on PC that contributes to removal of GB cells, a strategy that may be considered to be a promising new therapy against GB.

In summary, the use of pharmacologic inhibitors or genetic therapy to inhibit macroautophagy may prevent GB progression, but also promotes tumor immune tolerance. Therefore, future therapy in brain peritumoral areas against Lamp $2 a$ expression could inhibit more specifically GB survival, through impaired CMA, not only in the tumor cell but even in cells that interact with the tumor, preventing the immunosuppressive microenvironment that facilitates tumor survival.

\section{Conclusions and Future Perspectives}

It must be considered that systemic administration of any autophagy inhibitor/activator will not only affect tumor cells, but also all cell types present in the peritumoral microenvironment, a situation that could lead to the occurrence of serious side effects. Moreover, the possible anti-tumor strategy to be developed is further complicated considering that depending on the type of tumor cell or tumor stage, macroautophagy could act as a pro- or anti-tumorigenic mechanism $[3,73,81]$, a situation that hinders the eligibility of an inhibitor or an activator of macroautophagy. CMA could represent a more specific targetable mechanism to prevent GB progression, considering that current macroautophagy inhibitors may have effects on many other cell processes different to macroautophagy, while targeting Lamp2a gen may be specific for CMA.

Peritumoral areas, where GB progresses and where we can find tumor interactions with other cells facilitating tumor growth, are promising targets to be considered for new treatments after tumor surgery. As discussed above, genetic manipulations to block CMA in tumor cells or alternatively in peritumoral cells could be a suitable therapeutic option to prevent tumor survival and avoid its progression. However, CMA activity is also needed to maintain effector functions of T cells [89], which are of key importance for complete tumor removal. Collectively, the ideal treatment for GB could be constituted by a strategy that pursues the selective inhibition of CMA in the tumor and in the peritumoral microenvironment, specifically in those cells in which CMA favors tumor progression such as PC. Not less important would be to combine this treatment simultaneously with other therapeutic strategies that boost tumor antigen-specific $\mathrm{T}$ cell responses, allowing the complete removal of the 
tumor. Combined immunotherapies able to cross blood-brain barrier or intrathecal therapy [23] (i.e., monoclonal antibodies, peptides, pro-inflammatory cytokines, dendritic cell vaccines, high dose IL-2 (HDIL-2) immunotherapy or chimeric antigen receptor T (CART) cell therapy against GB [168,169]) could lead to improved therapeutic results.

In conclusion, CMA could be considered to be a critical mechanism to be exploited as a promising new gateway to enable an efficient anti-GB therapy.

Author Contributions: Each author has made substantial contributions to the completion of this review; has approved the submitted version; and agrees to be personally accountable for the author's own contributions and for any questions related to the content of the review. Contributions are: Conceptualization, R.V.; Writing-Original Draft Preparation, M.L.M., D.G.-B. and R.V.; Writing-Figures Preparation, M.L.M., D.G.-B. Review, and Editing, S.M. and R.V. All authors have read and agreed to the published version of the manuscript.

Funding: This study was funded mainly by Ministerio de Economia y Competitividad de España, MINECO SAF2015-73923-JIN, Agencia Estatal de Investigación/Fondos Europeos de Desarrollo Regional/ Union Europea (AEI/FEDER/UE). It was supported in part by funds from Seneca Foundation 20840/PI/18, ISCIII/Red de Terapia Celular, TERCEL (RD16/0011/0010 and RD16/0011/0001).

Acknowledgments: We thank F. Macian at Albert Einstein College of Medicine (New York), for his kind help to edit the manuscript.

Conflicts of Interest: The authors declare no conflict of interest.

\section{References}

1. Liu, E.Y.; Ryan, K.M. Autophagy and cancer-Issues we need to digest. J. Cell Sci. 2012, 125, $2349-2358$. [CrossRef]

2. Nazio, F.; Bordi, M.; Cianfanelli, V.; Locatelli, F.; Cecconi, F. Autophagy and cancer stem cells: Molecular mechanisms and therapeutic applications. Cell Death Differ. 2019, 26, 690-702. [CrossRef]

3. Galluzzi, L.; Bravo-San Pedro, J.M.; Kroemer, G. Autophagy Mediates Tumor Suppression via Cellular Senescence. Trends Cell Biol. 2016, 26, 1-3. [CrossRef]

4. Saha, T. LAMP2A overexpression in breast tumors promotes cancer cell survival via chaperone-mediated autophagy. Autophagy 2012, 8, 1643-1656. [CrossRef] [PubMed]

5. Kon, M.; Kiffin, R.; Koga, H.; Chapochnick, J.; Macian, F.; Varticovski, L.; Cuervo, A.M. Chaperone-mediated autophagy is required for tumor growth. Sci. Transl. Med. 2011, 3, 109ra117. [CrossRef] [PubMed]

6. Poillet-Perez, L.; Xie, X.; Zhan, L.; Yang, Y.; Sharp, D.W.; Hu, Z.S.; Su, X.; Maganti, A.; Jiang, C.; Lu, W.; et al. Autophagy maintains tumour growth through circulating arginine. Nature 2018, 563, 569-573. [CrossRef] [PubMed]

7. Galluzzi, L.; Pietrocola, F.; Bravo-San Pedro, J.M.; Amaravadi, R.K.; Baehrecke, E.H.; Cecconi, F.; Codogno, P.; Debnath, J.; Gewirtz, D.A.; Karantza, V.; et al. Autophagy in malignant transformation and cancer progression. EMBO J. 2015, 34, 856-880. [CrossRef]

8. Otvos, B.; Silver, D.J.; Mulkearns-Hubert, E.E.; Alvarado, A.G.; Turaga, S.M.; Sorensen, M.D.; Rayman, P.; Flavahan, W.A.; Hale, J.S.; Stoltz, K.; et al. Cancer Stem Cell-Secreted Macrophage Migration Inhibitory Factor Stimulates Myeloid Derived Suppressor Cell Function and Facilitates Glioblastoma Immune Evasion. Stem Cells 2016, 34, 2026-2039. [CrossRef]

9. Saha, D.; Martuza, R.L.; Rabkin, S.D. Macrophage Polarization Contributes to Glioblastoma Eradication by Combination Immunovirotherapy and Immune Checkpoint Blockade. Cancer Cell 2017, 32, $253-267$. [CrossRef]

10. Henrik Heiland, D.; Ravi, V.M.; Behringer, S.P.; Frenking, J.H.; Wurm, J.; Joseph, K.; Garrelfs, N.W.C.; Strahle, J.; Heynckes, S.; Grauvogel, J.; et al. Tumor-associated reactive astrocytes aid the evolution of immunosuppressive environment in glioblastoma. Nat. Commun. 2019, 10, 2541. [CrossRef]

11. Arrieta, V.A.; Cacho-Diaz, B.; Zhao, J.; Rabadan, R.; Chen, L.; Sonabend, A.M. The possibility of cancer immune editing in gliomas. A critical review. Oncoimmunology 2018, 7, e1445458. [CrossRef] [PubMed]

12. Farin, A.; Suzuki, S.O.; Weiker, M.; Goldman, J.E.; Bruce, J.N.; Canoll, P. Transplanted glioma cells migrate and proliferate on host brain vasculature: A dynamic analysis. Glia 2006, 53, 799-808. [CrossRef] [PubMed] 
13. Valdor, R.; Garcia-Bernal, D.; Bueno, C.; Rodenas, M.; Moraleda, J.M.; Macian, F.; Martinez, S. Glioblastoma progression is assisted by induction of immunosuppressive function of pericytes through interaction with tumor cells. Oncotarget 2017, 8, 68614-68626. [CrossRef] [PubMed]

14. Osswald, M.; Jung, E.; Sahm, F.; Solecki, G.; Venkataramani, V.; Blaes, J.; Weil, S.; Horstmann, H.; Wiestler, B.; Syed, M.; et al. Brain tumour cells interconnect to a functional and resistant network. Nature 2015, 528, $93-98$. [CrossRef] [PubMed]

15. Venkataramani, V.; Tanev, D.I.; Strahle, C.; Studier-Fischer, A.; Fankhauser, L.; Kessler, T.; Korber, C.; Kardorff, M.; Ratliff, M.; Xie, R.; et al. Glutamatergic synaptic input to glioma cells drives brain tumour progression. Nature 2019, 573, 532-538. [CrossRef]

16. Hjelmeland, A.B.; Lathia, J.D.; Sathornsumetee, S.; Rich, J.N. Twisted tango: Brain tumor neurovascular interactions. Nat. Neurosci. 2011, 14, 1375-1381. [CrossRef]

17. Clarke, A.J.; Simon, A.K. Autophagy in the renewal, differentiation and homeostasis of immune cells. Nat. Rev. Immunol. 2019, 19, 170-183. [CrossRef]

18. Deretic, V.; Levine, B. Autophagy balances inflammation in innate immunity. Autophagy 2018, 14, $243-251$. [CrossRef]

19. Munz, C. Autophagy proteins in antigen processing for presentation on MHC molecules. Immunol. Rev. 2016, 272, 17-27. [CrossRef]

20. Macian, F. Autophagy in T Cell Function and Aging. Front. Cell Dev. Biol. 2019, 7, 213. [CrossRef]

21. Janji, B.; Berchem, G.; Chouaib, S. Targeting Autophagy in the Tumor Microenvironment: New Challenges and Opportunities for Regulating Tumor Immunity. Front. Immunol. 2018, 9, 887. [CrossRef]

22. Nduom, E.K.; Weller, M.; Heimberger, A.B. Immunosuppressive mechanisms in glioblastoma. Neuro-Oncology 2015, 17 (Suppl. 7), vii9-vii14. [CrossRef]

23. Liang, X.; De Vera, M.E.; Buchser, W.J.; de Vivar Chavez, A.R.; Loughran, P.; Beer Stolz, D.; Basse, P.; Wang, T.; Van Houten, B.; Zeh, H.J., III; et al. Inhibiting systemic autophagy during interleukin 2 immunotherapy promotes long-term tumor regression. Cancer Res. 2012, 72, 2791-2801. [CrossRef] [PubMed]

24. Mejlvang, J.; Olsvik, H.; Svenning, S.; Bruun, J.A.; Abudu, Y.P.; Larsen, K.B.; Brech, A.; Hansen, T.E.; Brenne, H.; Hansen, T.; et al. Starvation induces rapid degradation of selective autophagy receptors by endosomal microautophagy. J. Cell Biol. 2018, 217, 3640-3655. [CrossRef] [PubMed]

25. Chauhan, A.S.; Kumar, M.; Chaudhary, S.; Dhiman, A.; Patidar, A.; Jakhar, P.; Jaswal, P.; Sharma, K.; Sheokand, N.; Malhotra, H.; et al. Trafficking of a multifunctional protein by endosomal microautophagy: Linking two independent unconventional secretory pathways. FASEB J. 2019, 33, 5626-5640. [CrossRef]

26. Quail, D.F.; Joyce, J.A. The Microenvironmental Landscape of Brain Tumors. Cancer Cell 2017, 31, $326-341$. [CrossRef]

27. Hambardzumyan, D.; Gutmann, D.H.; Kettenmann, H. The role of microglia and macrophages in glioma maintenance and progression. Nat. Neurosci. 2016, 19, 20-27. [CrossRef]

28. Lu-Emerson, C.; Snuderl, M.; Kirkpatrick, N.D.; Goveia, J.; Davidson, C.; Huang, Y.; Riedemann, L.; Taylor, J.; Ivy, P.; Duda, D.G.; et al. Increase in tumor-associated macrophages after antiangiogenic therapy is associated with poor survival among patients with recurrent glioblastoma. Neuro-Oncology 2013, 15, 1079-1087. [CrossRef]

29. Ye, X.Z.; Xu, S.L.; Xin, Y.H.; Yu, S.C.; Ping, Y.F.; Chen, L.; Xiao, H.L.; Wang, B.; Yi, L.; Wang, Q.L.; et al. Tumor-associated microglia/macrophages enhance the invasion of glioma stem-like cells via TGF-beta1 signaling pathway. J. Immunol. 2012, 189, 444-453. [CrossRef]

30. Nitta, T.; Hishii, M.; Sato, K.; Okumura, K. Selective expression of interleukin-10 gene within glioblastoma multiforme. Brain Res. 1994, 649, 122-128. [CrossRef]

31. Jacobs, J.F.; Idema, A.J.; Bol, K.F.; Nierkens, S.; Grauer, O.M.; Wesseling, P.; Grotenhuis, J.A.; Hoogerbrugge, P.M.; de Vries, I.J.; Adema, G.J. Regulatory T cells and the PD-L1/PD-1 pathway mediate immune suppression in malignant human brain tumors. Neuro-Oncology 2009, 11, 394-402. [CrossRef] [PubMed]

32. Reardon, D.A.; Freeman, G.; Wu, C.; Chiocca, E.A.; Wucherpfennig, K.W.; Wen, P.Y.; Fritsch, E.F.; Curry, W.T., Jr.; Sampson, J.H.; Dranoff, G. Immunotherapy advances for glioblastoma. Neuro-Oncology 2014, 16, 1441-1458. [CrossRef] [PubMed]

33. Balabanov, R.; Beaumont, T.; Dore-Duffy, P. Role of central nervous system microvascular pericytes in activation of antigen-primed splenic T-lymphocytes. J. Neurosci. Res. 1999, 55, 578-587. [CrossRef] 
34. Bose, A.; Barik, S.; Banerjee, S.; Ghosh, T.; Mallick, A.; Bhattacharyya Majumdar, S.; Goswami, K.K.; Bhuniya, A.; Banerjee, S.; Baral, R.; et al. Tumor-derived vascular pericytes anergize Th cells. J. Immunol. 2013, 191, 971-981. [CrossRef]

35. Caspani, E.M.; Crossley, P.H.; Redondo-Garcia, C.; Martinez, S. Glioblastoma: A pathogenic crosstalk between tumor cells and pericytes. PLoS ONE 2014, 9, e101402. [CrossRef]

36. Valdor, R.; Garcia-Bernal, D.; Riquelme, D.; Martinez, C.M.; Moraleda, J.M.; Cuervo, A.M.; Macian, F.; Martinez, S. Glioblastoma ablates pericytes antitumor immune function through aberrant up-regulation of chaperone-mediated autophagy. Proc. Natl. Acad. Sci. USA 2019, 116, 20655-20665. [CrossRef]

37. Sui, X.; Chen, R.; Wang, Z.; Huang, Z.; Kong, N.; Zhang, M.; Han, W.; Lou, F.; Yang, J.; Zhang, Q.; et al. Autophagy and chemotherapy resistance: A promising therapeutic target for cancer treatment. Cell Death Dis. 2013, 4, e838. [CrossRef]

38. Mizushima, N.; Yoshimori, T.; Ohsumi, Y. The role of Atg proteins in autophagosome formation. Annu. Rev. Cell Dev. Biol. 2011, 27, 107-132. [CrossRef]

39. Ohsumi, Y. Historical landmarks of autophagy research. Cell Res. 2014, 24, 9-23. [CrossRef]

40. Johansen, T.; Lamark, T. Selective Autophagy: ATG8 Family Proteins, LIR Motifs and Cargo Receptors. J. Mol. Biol. 2019. [CrossRef]

41. Stolz, A.; Ernst, A.; Dikic, I. Cargo recognition and trafficking in selective autophagy. Nat. Cell Biol. 2014, 16, 495-501. [CrossRef]

42. He, C.; Klionsky, D.J. Regulation mechanisms and signaling pathways of autophagy. Ann. Rev. Genet. 2009, 43, 67-93. [CrossRef]

43. Howarth, A.; Madureira, P.A.; Lockwood, G.; Storer, L.C.D.; Grundy, R.; Rahman, R.; Pilkington, G.J.; Hill, R. Modulating autophagy as a therapeutic strategy for the treatment of paediatric high-grade glioma. Brain Pathol. 2019, 29, 707-725. [CrossRef] [PubMed]

44. Martina, J.A.; Diab, H.I.; Lishu, L.; Jeong, A.L.; Patange, S.; Raben, N.; Puertollano, R. The nutrient-responsive transcription factor TFE3 promotes autophagy, lysosomal biogenesis, and clearance of cellular debris. Sci. Signal. 2014, 7, ra9. [CrossRef] [PubMed]

45. Settembre, C.; Medina, D.L. TFEB and the CLEAR network. Methods Cell Biol. 2015, 126, 45-62. [CrossRef] [PubMed]

46. Laurent, A.C.; Bisserier, M.; Lucas, A.; Tortosa, F.; Roumieux, M.; De Regibus, A.; Swiader, A.; Sainte-Marie, Y.; Heymes, C.; Vindis, C.; et al. Exchange protein directly activated by cAMP 1 promotes autophagy during cardiomyocyte hypertrophy. Cardiovasc. Res. 2015, 105, 55-64. [CrossRef]

47. Guha, P.; Tyagi, R.; Chowdhury, S.; Reilly, L.; Fu, C.; Xu, R.; Resnick, A.C.; Snyder, S.H. IPMK Mediates Activation of ULK Signaling and Transcriptional Regulation of Autophagy Linked to Liver Inflammation and Regeneration. Cell Rep. 2019, 26, 2692-2703.e7. [CrossRef]

48. Yang, J.; Yao, S. JNK-Bcl-2/Bcl-xL-Bax/Bak Pathway Mediates the Crosstalk between Matrine-Induced Autophagy and Apoptosis via Interplay with Beclin 1. Int. J. Mol. Sci. 2015, 16, 25744-25758. [CrossRef]

49. Zhong, L.; Shu, W.; Dai, W.; Gao, B.; Xiong, S. Reactive Oxygen Species-Mediated c-Jun NH2-Terminal Kinase Activation Contributes to Hepatitis B Virus X Protein-Induced Autophagy via Regulation of the Beclin-1/Bcl-2 Interaction. J. Virol. 2017, 91. [CrossRef]

50. Zhou, Y.Y.; Li, Y.; Jiang, W.Q.; Zhou, L.F. MAPK/JNK signalling: A potential autophagy regulation pathway. Biosci. Rep. 2015, 35. [CrossRef]

51. Jain, M.V.; Paczulla, A.M.; Klonisch, T.; Dimgba, F.N.; Rao, S.B.; Roberg, K.; Schweizer, F.; Lengerke, C.; Davoodpour, P.; Palicharla, V.R.; et al. Interconnections between apoptotic, autophagic and necrotic pathways: Implications for cancer therapy development. J. Cell. Mol. Med. 2013, 17, 12-29. [CrossRef] [PubMed]

52. Czarny, P.; Pawlowska, E.; Bialkowska-Warzecha, J.; Kaarniranta, K.; Blasiak, J. Autophagy in DNA damage response. Int. J. Mol. Sci. 2015, 16, 2641-2662. [CrossRef] [PubMed]

53. Zhou, Z.W.; Li, X.X.; He, Z.X.; Pan, S.T.; Yang, Y.; Zhang, X.; Chow, K.; Yang, T.; Qiu, J.X.; Zhou, Q.; et al. Induction of apoptosis and autophagy via sirtuin1- and PI3K/Akt/mTOR-mediated pathways by plumbagin in human prostate cancer cells. Drug Des. Dev. Ther. 2015, 9, 1511-1554. [CrossRef] [PubMed]

54. Cagnol, S.; Chambard, J.C. ERK and cell death: Mechanisms of ERK-induced cell death-apoptosis, autophagy and senescence. FEBS J. 2010, 277, 2-21. [CrossRef] [PubMed]

55. Samatar, A.A.; Poulikakos, P.I. Targeting RAS-ERK signalling in cancer: Promises and challenges. Nat. Rev. Drug Discov. 2014, 13, 928-942. [CrossRef] 
56. Yao, Z.Q.; Zhang, X.; Zhen, Y.; He, X.Y.; Zhao, S.; Li, X.F.; Yang, B.; Gao, F.; Guo, F.Y.; Fu, L.; et al. A novel small-molecule activator of Sirtuin-1 induces autophagic cell death/mitophagy as a potential therapeutic strategy in glioblastoma. Cell Death Dis. 2018, 9, 767. [CrossRef]

57. Ratovitski, E.A. Tumor Protein (TP)-p53 Members as Regulators of Autophagy in Tumor Cells upon Marine Drug Exposure. Mar. Drugs 2016, 14. [CrossRef]

58. Yuan, B.; Shimada, R.; Xu, K.; Han, L.; Si, N.; Zhao, H.; Bian, B.; Hayashi, H.; Okazaki, M.; Takagi, N. Multiple cytotoxic effects of gamabufotalin against human glioblastoma cell line U-87. Chem. Biol. Interact. 2019, 314, 108849. [CrossRef]

59. Jawhari, S.; Ratinaud, M.H.; Verdier, M. Glioblastoma, hypoxia and autophagy: A survival-prone 'menage-a-trois'. Cell Death Dis. 2016, 7, e2434. [CrossRef]

60. Maiuri, M.C.; Tasdemir, E.; Criollo, A.; Morselli, E.; Vicencio, J.M.; Carnuccio, R.; Kroemer, G. Control of autophagy by oncogenes and tumor suppressor genes. Cell Death Differ. 2009, 16, 87-93. [CrossRef]

61. Peng, F.; Wang, X.; Shu, M.; Yang, M.; Wang, L.; Ouyang, Z.; Shen, C.; Hou, X.; Zhao, B.; Wang, X.; et al. Raddeanin a Suppresses Glioblastoma Growth by Inducing ROS Generation and Subsequent JNK Activation to Promote Cell Apoptosis. Cell. Physiol. Biochem. 2018, 47, 1108-1121. [CrossRef]

62. Kania, E.; Roest, G.; Vervliet, T.; Parys, J.B.; Bultynck, G. IP3 Receptor-Mediated Calcium Signaling and Its Role in Autophagy in Cancer. Front. Oncol. 2017, 7, 140. [CrossRef] [PubMed]

63. Wang, Q.; Huang, L.; Yue, J. Oxidative stress activates the TRPM2-Ca(2+)-CaMKII-ROS signaling loop to induce cell death in cancer cells. Biochim. Biophys. Acta Mol. Cell Res. 2017, 1864, 957-967. [CrossRef] [PubMed]

64. Zeng, X.; Ju, D. Hedgehog Signaling Pathway and Autophagy in Cancer. Int. J. Mol. Sci. 2018, 19, 2279. [CrossRef]

65. Bartolini, D.; Dallaglio, K.; Torquato, P.; Piroddi, M.; Galli, F. Nrf2-p62 autophagy pathway and its response to oxidative stress in hepatocellular carcinoma. Transl. Res. 2018, 193, 54-71. [CrossRef]

66. Robainas, M.; Otano, R.; Bueno, S.; Ait-Oudhia, S. Understanding the role of PD-L1/PD1 pathway blockade and autophagy in cancer therapy. Oncotargets Ther. 2017, 10, 1803-1807. [CrossRef]

67. Sahu, R.; Kaushik, S.; Clement, C.C.; Cannizzo, E.S.; Scharf, B.; Follenzi, A.; Potolicchio, I.; Nieves, E.; Cuervo, A.M.; Santambrogio, L. Microautophagy of cytosolic proteins by late endosomes. Dev. Cell 2011, 20, 131-139. [CrossRef]

68. Mizushima, N.; Hara, T. Intracellular quality control by autophagy: How does autophagy prevent neurodegeneration? Autophagy 2006, 2, 302-304. [CrossRef]

69. Johansen, T.; Lamark, T. Selective autophagy mediated by autophagic adapter proteins. Autophagy 2011, 7 , 279-296. [CrossRef]

70. Fimia, G.M.; Kroemer, G.; Piacentini, M. Molecular mechanisms of selective autophagy. Cell Death Differ. 2013, 20, 1-2. [CrossRef]

71. Rogov, V.; Dotsch, V.; Johansen, T.; Kirkin, V. Interactions between autophagy receptors and ubiquitin-like proteins form the molecular basis for selective autophagy. Mol. Cell 2014, 53, 167-178. [CrossRef] [PubMed]

72. Zhang, T.; Shen, S.; Qu, J.; Ghaemmaghami, S. Global Analysis of Cellular Protein Flux Quantifies the Selectivity of Basal Autophagy. Cell Rep. 2016, 14, 2426-2439. [CrossRef] [PubMed]

73. Colella, B.; Faienza, F.; Di Bartolomeo, S. EMT Regulation by Autophagy: A New Perspective in Glioblastoma Biology. Cancers 2019, 11, 312. [CrossRef] [PubMed]

74. Fitzwalter, B.E.; Thorburn, A. Recent insights into cell death and autophagy. FEBS J. 2015, 282, 4279-4288. [CrossRef] [PubMed]

75. Liu, W.T.; Huang, C.Y.; Lu, I.C.; Gean, P.W. Inhibition of glioma growth by minocycline is mediated through endoplasmic reticulum stress-induced apoptosis and autophagic cell death. Neuro-Oncology 2013, 15, 1127-1141. [CrossRef]

76. Pallichankandy, S.; Rahman, A.; Thayyullathil, F.; Galadari, S. ROS-dependent activation of autophagy is a critical mechanism for the induction of anti-glioma effect of sanguinarine. Free Radic. Biol. Med. 2015, 89, 708-720. [CrossRef]

77. Rojas-Sanchez, G.; Cotzomi-Ortega, I.; Pazos-Salazar, N.G.; Reyes-Leyva, J.; Maycotte, P. Autophagy and Its Relationship to Epithelial to Mesenchymal Transition: When Autophagy Inhibition for Cancer Therapy Turns Counterproductive. Biology 2019, 8, 71. [CrossRef] 
78. Galavotti, S.; Bartesaghi, S.; Faccenda, D.; Shaked-Rabi, M.; Sanzone, S.; McEvoy, A.; Dinsdale, D.; Condorelli, F.; Brandner, S.; Campanella, M.; et al. The autophagy-associated factors DRAM1 and p62 regulate cell migration and invasion in glioblastoma stem cells. Oncogene 2013, 32, 699-712. [CrossRef]

79. Viry, E.; Baginska, J.; Berchem, G.; Noman, M.Z.; Medves, S.; Chouaib, S.; Janji, B. Autophagic degradation of GZMB/granzyme B: A new mechanism of hypoxic tumor cell escape from natural killer cell-mediated lysis. Autophagy 2014, 10, 173-175. [CrossRef]

80. Abdul Rahim, S.A.; Dirkse, A.; Oudin, A.; Schuster, A.; Bohler, J.; Barthelemy, V.; Muller, A.; Vallar, L.; Janji, B.; Golebiewska, A.; et al. Regulation of hypoxia-induced autophagy in glioblastoma involves ATG9A. Br. J. Cancer 2017, 117, 813-825. [CrossRef]

81. Gammoh, N.; Fraser, J.; Puente, C.; Syred, H.M.; Kang, H.; Ozawa, T.; Lam, D.; Acosta, J.C.; Finch, A.J.; Holland, E.; et al. Suppression of autophagy impedes glioblastoma development and induces senescence. Autophagy 2016, 12, 1431-1439. [CrossRef] [PubMed]

82. Dolma, S.; Selvadurai, H.J.; Lan, X.; Lee, L.; Kushida, M.; Voisin, V.; Whetstone, H.; So, M.; Aviv, T.; Park, N.; et al. Inhibition of Dopamine Receptor D4 Impedes Autophagic Flux, Proliferation, and Survival of Glioblastoma Stem Cells. Cancer Cell 2016, 29, 859-873. [CrossRef] [PubMed]

83. Zhang, C.; Zhang, X.; Xu, R.; Huang, B.; Chen, A.J.; Li, C.; Wang, J.; Li, X.G. TGF-beta2 initiates autophagy via Smad and non-Smad pathway to promote glioma cells' invasion. J. Exp. Clin. Cancer Res. 2017, 36, 162. [CrossRef] [PubMed]

84. Klionsky, D.J.; Abdelmohsen, K.; Abe, A.; Abedin, M.J.; Abeliovich, H.; Acevedo Arozena, A.; Adachi, H.; Adams, C.M.; Adams, P.D.; Adeli, K.; et al. Guidelines for the use and interpretation of assays for monitoring autophagy (3rd edition). Autophagy 2016, 12, 1-222. [CrossRef]

85. Kaushik, S.; Cuervo, A.M. The coming of age of chaperone-mediated autophagy. Nat. Rev. Mol. Cell Biol. 2018, 19, 365-381. [CrossRef]

86. Cuervo, A.M.; Dice, J.F. A receptor for the selective uptake and degradation of proteins by lysosomes. Science 1996, 273, 501-503. [CrossRef]

87. Kiffin, R.; Christian, C.; Knecht, E.; Cuervo, A.M. Activation of chaperone-mediated autophagy during oxidative stress. Mol. Biol. Cell 2004, 15, 4829-4840. [CrossRef]

88. Massey, A.C.; Kaushik, S.; Sovak, G.; Kiffin, R.; Cuervo, A.M. Consequences of the selective blockage of chaperone-mediated autophagy. Proc. Natl. Acad. Sci. USA 2006, 103, 5805-5810. [CrossRef]

89. Valdor, R.; Mocholi, E.; Botbol, Y.; Guerrero-Ros, I.; Chandra, D.; Koga, H.; Gravekamp, C.; Cuervo, A.M.; Macian, F. Chaperone-mediated autophagy regulates $\mathrm{T}$ cell responses through targeted degradation of negative regulators of $\mathrm{T}$ cell activation. Nat. Immunol. 2014, 15, 1046-1054. [CrossRef]

90. Hubbi, M.E.; Hu, H.; Kshitiz; Ahmed, I.; Levchenko, A.; Semenza, G.L. Chaperone-mediated autophagy targets hypoxia-inducible factor-1alpha (HIF-1alpha) for lysosomal degradation. J. Biol. Chem. 2013, 288, 10703-10714. [CrossRef]

91. Dice, J.F. Altered degradation of proteins microinjected into senescent human fibroblasts. J. Biol. Chem. 1982, 257, 14624-14627. [PubMed]

92. Cuervo, A.M.; Knecht, E.; Terlecky, S.R.; Dice, J.F. Activation of a selective pathway of lysosomal proteolysis in rat liver by prolonged starvation. Am. J. Physiol. 1995, 269, C1200-C1208. [CrossRef] [PubMed]

93. Finn, P.F.; Dice, J.F. Ketone bodies stimulate chaperone-mediated autophagy. J. Biol. Chem. 2005, 280, 25864-25870. [CrossRef] [PubMed]

94. Arias, E.; Cuervo, A.M. Pros and Cons of Chaperone-Mediated Autophagy in Cancer Biology. Trends Endocrinol. Metab. 2019, 31, 53-66. [CrossRef] [PubMed]

95. Zhang, S.; Hu, B.; You, Y.; Yang, Z.; Liu, L.; Tang, H.; Bao, W.; Guan, Y.; Shen, X. Sorting nexin 10 acts as a tumor suppressor in tumorigenesis and progression of colorectal cancer through regulating chaperone mediated autophagy degradation of p21(Cip1/WAF1). Cancer Lett. 2018, 419, 116-127. [CrossRef] [PubMed]

96. Xia, H.G.; Najafov, A.; Geng, J.; Galan-Acosta, L.; Han, X.; Guo, Y.; Shan, B.; Zhang, Y.; Norberg, E.; Zhang, T.; et al. Degradation of HK2 by chaperone-mediated autophagy promotes metabolic catastrophe and cell death. J. Cell Biol. 2015, 210, 705-716. [CrossRef]

97. Cuervo, A.M.; Dice, J.F. Regulation of lamp2a levels in the lysosomal membrane. Traffic 2000, 1, 570-583. [CrossRef] 
98. Xue, N.; Lai, F.; Du, T.; Ji, M.; Liu, D.; Yan, C.; Zhang, S.; Yu, X.; Jin, J.; Chen, X. Chaperone-mediated autophagy degradation of IGF-1Rbeta induced by NVP-AUY922 in pancreatic cancer. Cell. Mol. Life Sci. 2019, 76, 3433-3447. [CrossRef]

99. Arias, E.; Koga, H.; Diaz, A.; Mocholi, E.; Patel, B.; Cuervo, A.M. Lysosomal mTORC2/PHLPP1/Akt Regulate Chaperone-Mediated Autophagy. Mol. Cell 2015, 59, 270-284. [CrossRef]

100. Schneider, J.L.; Suh, Y.; Cuervo, A.M. Deficient chaperone-mediated autophagy in liver leads to metabolic dysregulation. Cell Metab. 2014, 20, 417-432. [CrossRef]

101. Rodriguez-Muela, N.; Koga, H.; Garcia-Ledo, L.; de la Villa, P.; de la Rosa, E.J.; Cuervo, A.M.; Boya, P. Balance between autophagic pathways preserves retinal homeostasis. Aging Cell 2013, 12, 478-488. [CrossRef] [PubMed]

102. Kaushik, S.; Massey, A.C.; Mizushima, N.; Cuervo, A.M. Constitutive activation of chaperone-mediated autophagy in cells with impaired macroautophagy. Mol. Biol. Cell 2008, 19, 2179-2192. [CrossRef] [PubMed]

103. Koga, H.; Martinez-Vicente, M.; Macian, F.; Verkhusha, V.V.; Cuervo, A.M. A photoconvertible fluorescent reporter to track chaperone-mediated autophagy. Nat. Commun. 2011, 2, 386. [CrossRef] [PubMed]

104. Chava, S.; Lee, C.; Aydin, Y.; Chandra, P.K.; Dash, A.; Chedid, M.; Thung, S.N.; Moroz, K.; Wu, T.; Nayak, N.C.; et al. Chaperone-mediated autophagy compensates for impaired macroautophagy in the cirrhotic liver to promote hepatocellular carcinoma. Oncotarget 2017, 8, 40019-40036. [CrossRef] [PubMed]

105. Gomes, L.R.; Menck, C.F.M.; Cuervo, A.M. Chaperone-mediated autophagy prevents cellular transformation by regulating MYC proteasomal degradation. Autophagy 2017, 13, 928-940. [CrossRef] [PubMed]

106. Zhou, J.; Yang, J.; Fan, X.; Hu, S.; Zhou, F.; Dong, J.; Zhang, S.; Shang, Y.; Jiang, X.; Guo, H.; et al. Chaperone-mediated autophagy regulates proliferation by targeting RND3 in gastric cancer. Autophagy 2016, 12, 515-528. [CrossRef]

107. Quintavalle, C.; Di Costanzo, S.; Zanca, C.; Tasset, I.; Fraldi, A.; Incoronato, M.; Mirabelli, P.; Monti, M.; Ballabio, A.; Pucci, P.; et al. Phosphorylation-regulated degradation of the tumor-suppressor form of PED by chaperone-mediated autophagy in lung cancer cells. J. Cell. Physiol. 2014, 229, 1359-1368. [CrossRef]

108. Lu, W.; Zhang, Y.; McDonald, D.O.; Jing, H.; Carroll, B.; Robertson, N.; Zhang, Q.; Griffin, H.; Sanderson, S.; Lakey, J.H.; et al. Dual proteolytic pathways govern glycolysis and immune competence. Cell 2014, 159, 1578-1590. [CrossRef]

109. Lv, L.; Li, D.; Zhao, D.; Lin, R.; Chu, Y.; Zhang, H.; Zha, Z.; Liu, Y.; Li, Z.; Xu, Y.; et al. Acetylation targets the M2 isoform of pyruvate kinase for degradation through chaperone-mediated autophagy and promotes tumor growth. Mol. Cell 2011, 42, 719-730. [CrossRef]

110. Li, L.; Fang, R.; Liu, B.; Shi, H.; Wang, Y.; Zhang, W.; Zhang, X.; Ye, L. Deacetylation of tumor-suppressor MST1 in Hippo pathway induces its degradation through HBXIP-elevated HDAC6 in promotion of breast cancer growth. Oncogene 2016, 35, 4048-4057. [CrossRef]

111. Park, C.; Suh, Y.; Cuervo, A.M. Regulated degradation of Chk1 by chaperone-mediated autophagy in response to DNA damage. Nat. Commun. 2015, 6, 6823. [CrossRef] [PubMed]

112. Ferreira, J.V.; Fofo, H.; Bejarano, E.; Bento, C.F.; Ramalho, J.S.; Girao, H.; Pereira, P. STUB1/CHIP is required for HIF1A degradation by chaperone-mediated autophagy. Autophagy 2013, 9, 1349-1366. [CrossRef] [PubMed]

113. Hubbi, M.E.; Gilkes, D.M.; Hu, H.; Kshitiz; Ahmed, I.; Semenza, G.L. Cyclin-dependent kinases regulate lysosomal degradation of hypoxia-inducible factor 1alpha to promote cell-cycle progression. Proc. Natl. Acad. Sci. USA 2014, 111, E3325-E3334. [CrossRef] [PubMed]

114. Hao, Y.; Kacal, M.; Ouchida, A.T.; Zhang, B.; Norberg, E.; Vakifahmetoglu-Norberg, H. Targetome analysis of chaperone-mediated autophagy in cancer cells. Autophagy 2019, 15, 1558-1571. [CrossRef]

115. Lo Dico, A.; Martelli, C.; Diceglie, C.; Lucignani, G.; Ottobrini, L. Hypoxia-Inducible Factor-1alpha Activity as a Switch for Glioblastoma Responsiveness to Temozolomide. Front. Oncol. 2018, 8, 249. [CrossRef]

116. Zhang, Y.; Morgan, M.J.; Chen, K.; Choksi, S.; Liu, Z.G. Induction of autophagy is essential for monocyte-macrophage differentiation. Blood 2012, 119, 2895-2905. [CrossRef]

117. Chen, P.; Cescon, M.; Bonaldo, P. Autophagy-mediated regulation of macrophages and its applications for cancer. Autophagy 2014, 10, 192-200. [CrossRef]

118. Liu, K.; Zhao, E.; Ilyas, G.; Lalazar, G.; Lin, Y.; Haseeb, M.; Tanaka, K.E.; Czaja, M.J. Impaired macrophage autophagy increases the immune response in obese mice by promoting proinflammatory macrophage polarization. Autophagy 2015, 11, 271-284. [CrossRef] 
119. Germic, N.; Frangez, Z.; Yousefi, S.; Simon, H.U. Regulation of the innate immune system by autophagy: Monocytes, macrophages, dendritic cells and antigen presentation. Cell Death Differ. 2019, 26, 715-727. [CrossRef]

120. Massara, M.; Persico, P.; Bonavita, O.; Mollica Poeta, V.; Locati, M.; Simonelli, M.; Bonecchi, R. Neutrophils in Gliomas. Front. Immunol. 2017, 8, 1349. [CrossRef]

121. Bhattacharya, A.; Wei, Q.; Shin, J.N.; Abdel Fattah, E.; Bonilla, D.L.; Xiang, Q.; Eissa, N.T. Autophagy Is Required for Neutrophil-Mediated Inflammation. Cell Rep. 2015, 12, 1731-1739. [CrossRef] [PubMed]

122. Skendros, P.; Mitroulis, I.; Ritis, K. Autophagy in Neutrophils: From Granulopoiesis to Neutrophil Extracellular Traps. Front. Cell Dev. Biol. 2018, 6, 109. [CrossRef] [PubMed]

123. Cho, M.H.; Cho, K.; Kang, H.J.; Jeon, E.Y.; Kim, H.S.; Kwon, H.J.; Kim, H.M.; Kim, D.H.; Yoon, S.Y. Autophagy in microglia degrades extracellular beta-amyloid fibrils and regulates the NLRP3 inflammasome. Autophagy 2014, 10, 1761-1775. [CrossRef] [PubMed]

124. Ye, J.; Jiang, Z.; Chen, X.; Liu, M.; Li, J.; Liu, N. The role of autophagy in pro-inflammatory responses of microglia activation via mitochondrial reactive oxygen species in vitro. J. Neurochem. 2017, 142, 215-230. [CrossRef] [PubMed]

125. Plaza-Zabala, A.; Sierra-Torre, V.; Sierra, A. Autophagy and Microglia: Novel Partners in Neurodegeneration and Aging. Int. J. Mol. Sci. 2017, 18, 598. [CrossRef]

126. Houtman, J.; Freitag, K.; Gimber, N.; Schmoranzer, J.; Heppner, F.L.; Jendrach, M. Beclin1-driven autophagy modulates the inflammatory response of microglia via NLRP3. EMBO J. 2019, 38. [CrossRef]

127. Di Malta, C.; Fryer, J.D.; Settembre, C.; Ballabio, A. Autophagy in astrocytes: A novel culprit in lysosomal storage disorders. Autophagy 2012, 8, 1871-1872. [CrossRef]

128. Moruno-Manchon, J.F.; Uzor, N.E.; Ambati, C.R.; Shetty, V.; Putluri, N.; Jagannath, C.; McCullough, L.D.; Tsvetkov, A.S. Sphingosine kinase 1-associated autophagy differs between neurons and astrocytes. Cell Death Dis. 2018, 9, 521. [CrossRef]

129. Periyasamy, P.; Guo, M.L.; Buch, S. Cocaine induces astrocytosis through ER stress-mediated activation of autophagy. Autophagy 2016, 12, 1310-1329. [CrossRef]

130. Chen, Z.; Nie, S.D.; Qu, M.L.; Zhou, D.; Wu, L.Y.; Shi, X.J.; Ma, L.R.; Li, X.; Zhou, S.L.; Wang, S.; et al. The autophagic degradation of Cav-1 contributes to PA-induced apoptosis and inflammation of astrocytes. Cell Death Dis. 2018, 9, 771. [CrossRef]

131. Pua, H.H.; He, Y.W. Mitophagy in the little lymphocytes: An essential role for autophagy in mitochondrial clearance in T lymphocytes. Autophagy 2009, 5, 745-746. [CrossRef] [PubMed]

132. Jia, W.; Pua, H.H.; Li, Q.J.; He, Y.W. Autophagy regulates endoplasmic reticulum homeostasis and calcium mobilization in T lymphocytes. J. Immunol. 2011, 186, 1564-1574. [CrossRef] [PubMed]

133. Hubbard, V.M.; Valdor, R.; Patel, B.; Singh, R.; Cuervo, A.M.; Macian, F. Macroautophagy regulates energy metabolism during effector T cell activation. J. Immunol. 2010, 185, 7349-7357. [CrossRef] [PubMed]

134. Mocholi, E.; Dowling, S.D.; Botbol, Y.; Gruber, R.C.; Ray, A.K.; Vastert, S.; Shafit-Zagardo, B.; Coffer, P.J.; Macian, F. Autophagy Is a Tolerance-Avoidance Mechanism that Modulates TCR-Mediated Signaling and Cell Metabolism to Prevent Induction of T Cell Anergy. Cell Rep. 2018, 24, 1136-1150. [CrossRef] [PubMed]

135. Botbol, Y.; Patel, B.; Macian, F. Common gamma-chain cytokine signaling is required for macroautophagy induction during CD4 ${ }^{+}$T-cell activation. Autophagy 2015, 11, 1864-1877. [CrossRef] [PubMed]

136. Matsuzawa, T.; Kim, B.H.; Shenoy, A.R.; Kamitani, S.; Miyake, M.; Macmicking, J.D. IFN-gamma elicits macrophage autophagy via the p38 MAPK signaling pathway. J. Immunol. 2012, 189, 813-818. [CrossRef]

137. Wei, J.; Long, L.; Yang, K.; Guy, C.; Shrestha, S.; Chen, Z.; Wu, C.; Vogel, P.; Neale, G.; Green, D.R.; et al. Autophagy enforces functional integrity of regulatory $\mathrm{T}$ cells by coupling environmental cues and metabolic homeostasis. Nat. Immunol. 2016, 17, 277-285. [CrossRef]

138. Xu, X.; Araki, K.; Li, S.; Han, J.H.; Ye, L.; Tan, W.G.; Konieczny, B.T.; Bruinsma, M.W.; Martinez, J.; Pearce, E.L.; et al. Autophagy is essential for effector CD8(+) T cell survival and memory formation. Nat. Immunol. 2014, 15, 1152-1161. [CrossRef]

139. DeVorkin, L.; Pavey, N.; Carleton, G.; Comber, A.; Ho, C.; Lim, J.; McNamara, E.; Huang, H.; Kim, P.; Zacharias, L.G.; et al. Autophagy Regulation of Metabolism Is Required for CD8(+) T Cell Anti-tumor Immunity. Cell Rep. 2019, 27, 502-513. [CrossRef] 
140. Vodnala, S.K.; Eil, R.; Kishton, R.J.; Sukumar, M.; Yamamoto, T.N.; Ha, N.H.; Lee, P.H.; Shin, M.; Patel, S.J.; $\mathrm{Yu}, \mathrm{Z}$; et al. T cell stemness and dysfunction in tumors are triggered by a common mechanism. Science 2019, 363, eaau0135. [CrossRef]

141. Candolfi, M.; Curtin, J.F.; Yagiz, K.; Assi, H.; Wibowo, M.K.; Alzadeh, G.E.; Foulad, D.; Muhammad, A.K.; Salehi, S.; Keech, N.; et al. B cells are critical to T-cell-mediated antitumor immunity induced by a combined immune-stimulatory/conditionally cytotoxic therapy for glioblastoma. Neoplasia 2011, 13, 947-960. [CrossRef] [PubMed]

142. Zhang, C.; Li, J.; Wang, H.; Song, S.W. Identification of a five B cell-associated gene prognostic and predictive signature for advanced glioma patients harboring immunosuppressive subtype preference. Oncotarget 2016, 7, 73971-73983. [CrossRef] [PubMed]

143. Xia, F.; Deng, C.; Jiang, Y.; Qu, Y.; Deng, J.; Cai, Z.; Ding, Y.; Guo, Z.; Wang, J. IL4 (interleukin 4) induces autophagy in B cells leading to exacerbated asthma. Autophagy 2018, 14, 450-464. [CrossRef] [PubMed]

144. Arnold, J.; Murera, D.; Arbogast, F.; Fauny, J.D.; Muller, S.; Gros, F. Autophagy is dispensable for B-cell development but essential for humoral autoimmune responses. Cell Death Differ. 2016, 23, 853-864. [CrossRef]

145. Miller, B.C.; Zhao, Z.; Stephenson, L.M.; Cadwell, K.; Pua, H.H.; Lee, H.K.; Mizushima, N.N.; Iwasaki, A.; He, Y.W.; Swat, W.; et al. The autophagy gene ATG5 plays an essential role in B lymphocyte development. Autophagy 2008, 4, 309-314. [CrossRef]

146. Liu, L.; An, D.; Xu, J.; Shao, B.; Li, X.; Shi, J. Ac2-26 Induces IKKbeta Degradation Through Chaperone-Mediated Autophagy Via HSPB1 in NCM-Treated Microglia. Front. Mol. Neurosci. 2018, 11, 76. [CrossRef]

147. di Domenico, A.; Carola, G.; Calatayud, C.; Pons-Espinal, M.; Munoz, J.P.; Richaud-Patin, Y.; Fernandez-Carasa, I.; Gut, M.; Faella, A.; Parameswaran, J.; et al. Patient-Specific iPSC-Derived Astrocytes Contribute to Non-Cell-Autonomous Neurodegeneration in Parkinson's Disease. Stem Cell Rep. 2019, 12, 213-229. [CrossRef]

148. Wang, R.; Liu, Y.; Liu, L.; Chen, M.; Wang, X.; Yang, J.; Gong, Y.; Ding, B.S.; Wei, Y.; Wei, X. Tumor cells induce LAMP2a expression in tumor-associated macrophage for cancer progression. EBioMedicine 2019, 40, 118-134. [CrossRef]

149. Perez, L.; McLetchie, S.; Gardiner, G.J.; Deffit, S.N.; Zhou, D.; Blum, J.S. LAMP-2C Inhibits MHC Class II Presentation of Cytoplasmic Antigens by Disrupting Chaperone-Mediated Autophagy. J. Immunol. 2016, 196, 2457-2465. [CrossRef]

150. Zhou, D.; Li, P.; Lin, Y.; Lott, J.M.; Hislop, A.D.; Canaday, D.H.; Brutkiewicz, R.R.; Blum, J.S. Lamp-2a facilitates MHC class II presentation of cytoplasmic antigens. Immunity 2005, 22, 571-581. [CrossRef]

151. Perera, R.M.; Stoykova, S.; Nicolay, B.N.; Ross, K.N.; Fitamant, J.; Boukhali, M.; Lengrand, J.; Deshpande, V.; Selig, M.K.; Ferrone, C.R.; et al. Transcriptional control of autophagy-lysosome function drives pancreatic cancer metabolism. Nature 2015, 524, 361-365. [CrossRef] [PubMed]

152. Wei, H.; Wei, S.; Gan, B.; Peng, X.; Zou, W.; Guan, J.L. Suppression of autophagy by FIP200 deletion inhibits mammary tumorigenesis. Genes Dev. 2011, 25, 1510-1527. [CrossRef] [PubMed]

153. Sotelo, J.; Briceno, E.; Lopez-Gonzalez, M.A. Adding chloroquine to conventional treatment for glioblastoma multiforme: A randomized, double-blind, placebo-controlled trial. Ann. Intern. Med. 2006, 144, 337-343. [CrossRef]

154. Rosenfeld, M.R.; Ye, X.; Supko, J.G.; Desideri, S.; Grossman, S.A.; Brem, S.; Mikkelson, T.; Wang, D.; Chang, Y.C.; Hu, J.; et al. A phase I/II trial of hydroxychloroquine in conjunction with radiation therapy and concurrent and adjuvant temozolomide in patients with newly diagnosed glioblastoma multiforme. Autophagy 2014, 10, 1359-1368. [CrossRef] [PubMed]

155. Filippi-Chiela, E.C.; Thome, M.P.; Bueno e Silva, M.M.; Pelegrini, A.L.; Ledur, P.F.; Garicochea, B.; Zamin, L.L.; Lenz, G. Resveratrol abrogates the temozolomide-induced G2 arrest leading to mitotic catastrophe and reinforces the temozolomide-induced senescence in glioma cells. BMC Cancer 2013, 13, 147. [CrossRef] [PubMed]

156. Wu, Y.T.; Tan, H.L.; Shui, G.; Bauvy, C.; Huang, Q.; Wenk, M.R.; Ong, C.N.; Codogno, P.; Shen, H.M. Dual role of 3-methyladenine in modulation of autophagy via different temporal patterns of inhibition on class I and III phosphoinositide 3-kinase. J. Biol. Chem. 2010, 285, 10850-10861. [CrossRef]

157. Rubinsztein, D.C.; Gestwicki, J.E.; Murphy, L.O.; Klionsky, D.J. Potential therapeutic applications of autophagy. Nat. Rev. Drug Discov. 2007, 6, 304-312. [CrossRef] 
158. Shchors, K.; Massaras, A.; Hanahan, D. Dual Targeting of the Autophagic Regulatory Circuitry in Gliomas with Repurposed Drugs Elicits Cell-Lethal Autophagy and Therapeutic Benefit. Cancer Cell 2015, 28, 456-471. [CrossRef]

159. Pajares, M.; Rojo, A.I.; Arias, E.; Diaz-Carretero, A.; Cuervo, A.M.; Cuadrado, A. Transcription factor NFE2L2/NRF2 modulates chaperone-mediated autophagy through the regulation of LAMP2A. Autophagy 2018, 14, 1310-1322. [CrossRef]

160. Anguiano, J.; Garner, T.P.; Mahalingam, M.; Das, B.C.; Gavathiotis, E.; Cuervo, A.M. Chemical modulation of chaperone-mediated autophagy by retinoic acid derivatives. Nat. Chem. Biol. 2013, 9, 374-382. [CrossRef]

161. Li, W.; Zhu, J.; Dou, J.; She, H.; Tao, K.; Xu, H.; Yang, Q.; Mao, Z. Phosphorylation of LAMP2A by p38 MAPK couples ER stress to chaperone-mediated autophagy. Nat. Commun. 2017, 8, 1763. [CrossRef] [PubMed]

162. Macri, C.; Wang, F.; Tasset, I.; Schall, N.; Page, N.; Briand, J.P.; Cuervo, A.M.; Muller, S. Modulation of deregulated chaperone-mediated autophagy by a phosphopeptide. Autophagy 2015, 11, 472-486. [CrossRef] [PubMed]

163. Perez, L.; Sinn, A.L.; Sandusky, G.E.; Pollok, K.E.; Blum, J.S. Melanoma LAMP-2C Modulates Tumor Growth and Autophagy. Front. Cell Dev. Biol. 2018, 6, 101. [CrossRef] [PubMed]

164. Finn, P.F.; Mesires, N.T.; Vine, M.; Dice, J.F. Effects of small molecules on chaperone-mediated autophagy. Autophagy 2005, 1, 141-145. [CrossRef] [PubMed]

165. Miyata, Y. Hsp90 inhibitor geldanamycin and its derivatives as novel cancer chemotherapeutic agents. Curr. Pharm. Des. 2005, 11, 1131-1138. [CrossRef] [PubMed]

166. Fukuyo, Y.; Hunt, C.R.; Horikoshi, N. Geldanamycin and its anti-cancer activities. Cancer Lett. 2010, 290, 24-35. [CrossRef]

167. Ding, Z.B.; Fu, X.T.; Shi, Y.H.; Zhou, J.; Peng, Y.F.; Liu, W.R.; Shi, G.M.; Gao, Q.; Wang, X.Y.; Song, K.; et al. Lamp2a is required for tumor growth and promotes tumor recurrence of hepatocellular carcinoma. Int. J. Oncol. 2016, 49, 2367-2376. [CrossRef]

168. Mitchell, D.A.; Batich, K.A.; Gunn, M.D.; Huang, M.N.; Sanchez-Perez, L.; Nair, S.K.; Congdon, K.L.; Reap, E.A.; Archer, G.E.; Desjardins, A.; et al. Tetanus toxoid and CCL3 improve dendritic cell vaccines in mice and glioblastoma patients. Nature 2015, 519, 366-369. [CrossRef]

169. Brown, C.E.; Alizadeh, D.; Starr, R.; Weng, L.; Wagner, J.R.; Naranjo, A.; Ostberg, J.R.; Blanchard, M.S.; Kilpatrick, J.; Simpson, J.; et al. Regression of Glioblastoma after Chimeric Antigen Receptor T-Cell Therapy. N. Engl. J. Med. 2016, 375, 2561-2569. [CrossRef]

(C) 2019 by the authors. Licensee MDPI, Basel, Switzerland. This article is an open access article distributed under the terms and conditions of the Creative Commons Attribution (CC BY) license (http://creativecommons.org/licenses/by/4.0/). 